\title{
DINAMIKA INTERAKSI ANTARA ELITE POLITIK LOKAL DAN ELITE AGAMA DALAM KONTESTASI PEMILIHAN PRESIDEN 2019 DI KOTA PASURUAN
}

\author{
Farid $^{1}$, Priyatmoko ${ }^{2}$ \\ ${ }^{1}$ Departemen Politik, Fakultas Ilmu Sosial dan Ilmu Politik, Universitas Airlangga \\ farid-2014@fisip.unair.ac.id \\ ${ }^{2}$ Departemen Politik, Fakultas Ilmu Sosial dan Ilmu Politik, Universitas Airlangga \\ priyatmoko@fisip.unair.ac.od
}

\begin{abstract}
The study focuses on the political phenomenon of the dynamic interaction between the local political elites and the religious elites in the contestation of the 2019 presidential elections. In this case of the contestation of presidential elections 2019, each has an influential elite in the community. The subject in this study to the political elites was a member of the Regional House of Representatives and Leaders of political parties in Pasuruan City. Furthermore, regarding the religious elites, it is a religious figure or religious leader who has an educational institution or a mass. The analysis study conducted is to use the main data obtained from an interview to the subject of the researcher and the secondary data information obtained from other supporting documents. The results of the research resulted in the findings of the Interaction dynamics between local political elites and religious elites in Pasuruan City during the 2019 Presidential Election. This interaction aims to win the candidate of the 2019 presidential spouse in Pasuruan city. Religious Elites and Local political elites in Pasuruan City each have the same interests. This interest is to win each of the spouses supported presidential candidates. The local political elites and religious elites are trying to win presidential candidates in a variety of ways. It starts with an open declaration until the indirect support. The religious elites in Pasuruan City have an important role in every election activity. Therefore, in the election activities will occur the dynamic interaction between the political elites and religious elites.
\end{abstract}

Keywords: Dynamics of interaction of local political elites, religious elites, 2019 presidential election.

\section{PENDAHULUAN}

Pasuruan adalah kota yang dikenal dengan kota santri atau pesantren yang didominasi oleh masyarakat Islam. Hal ini juga seirama dengan partai politik yang berkuasa di daerah tersebut, di mana partai PKB menjadi partai Islam dengan basis masyarakat nahdiyyin yang berkuasa di wilayah tersebut. Partai PKB berkuasa dengan perolehan kursi yang mencapai 37\% dengan jumlah kursi 11 dari total 30 kursi pada periode 2014-2019 (Kominfo, 2018). PKB dalam dunia politik di Kota Pasuruan mengambil peran sentral di Kota Pasuruan. Pendekatannya yang dilakukan adalah dengan mendekati tokoh agama atau ulama' yang ada di Kota Pasuruan. Dalam hal ini juga dapat diliat dalam peristiwa politik yang terjadi dalam pemilihan kepala daerah Jawa Timur 2018. Dalam kasus ini PKB menjadi partai pengusung pasangan Gus Ipul pasangan Gus Ipul dan Putih untuk menjadi Gubernur Jawa Timur periode 2019-2024.

Pendekatan yang dilakukan oleh partai PKB dengan menggandeng salah satu ulama' di Kota Pasuruan untuk memberikan maklumat dukungan kepada pasangan Gus Ipul. Adapun petikan maklumatnya adalah "semua alumni, warga santri putra dan putri Salafiyah dan Bayt Al Hikmah harus tetap merapatkan dukungan kepada Drs H Saifullah Yusuf”. Bentuk Petikan maklumat dukungan oleh 
KH Idris Hamid Pasuruan adalah bagian dari cara sebagai elite agama yang mempunyai kekuasaan di tengah masyarakat (Connstantine, 2018).

Suzanne Keller menjelaskan dalam sebuah konsep tentang elite. Elite adalah suatu kelompok kecil masyarakat yang mendominasi dalam masyarakat itu sendiri. Kyai sebagai sosok elite yang mendominasi dan mempunyai kedudukan di tengah masyarakat. Bentuk keterlibatan kyai dalam dunia politik mempunyai beragam cara. Dimulai dengan terjun langsung dalam dunia politik hingga menjalin komunikasi-komunikasi dengan elite politik yang hendak bertarung dalam kompetisi pemilu 2019 . Fenomena politik ini menjadi hal yang menarik untuk diteliti, apabila hal ini dikaji dalam Pilpres tahun 2019.

Fenomena dinamika interaksi antara elite politik lokal dan elite agama dimungkinkan terjadi dalam pilpres tahun 2019. Hal ini disebabkan dengan peristiwa politik yang terjadi dalam pemilihan presiden tahun 2019. Di mana dalam pemilihan presiden tahun 2019 terjadi pertarungan antara sosok kyai yang terjun dalam politik secara langsung hingga tidak. Dalam kontestasi pemilihan presiden tahun 2019 pasangan Joko Widodo-Ma'ruf Amin mempunyai latar belakang sebagai mantan ketua MUI (Majelis Ulama' Indonesia). Sementara untuk pasangan Prabowo - Sandi tidak memiliki latar belakang sebagai kyai. Namun pasangan Prabowo - Sandi mendapatkan dukungan kuat dari Habib dan Kyai yang tergabung dalam forum Ijtima' Ulama'.

Kota Pasuruan sebelumnya dijelaskan sebagai kota santri di mana terdapat banyak ulama' dan kyai yang berada disana. Ulama' dan kyai di kota Pasuruan memiliki pilihan tersendiri tentang sosok calon presiden dan wakil presiden yang hendak dipilih. Sementara itu elite politik lokal yang duduk di DPRD dan Walikota Kota Pasuruan juga didominasi oleh partai pengusung dari Jokowi-Ma'ruf amin. Di mana DPRD Kota Pasuruan pada tahun 2014-2019 berasal dari partai PKB dengan 10 kursi. Selanjutnya partai Golkar dengan 5 kursi serta urutan ketiga diisi oleh partai PDI-P. Dalam sisi eksekutif di mana Walikota

berasal dari partai Golkar dan PDI-P yang mendukung Jokowi-Ma'ruf (Kominfo, 2018). Oleh karena itu, peneliti tertarik untuk meneliti bagaimana dinamika interaksi antara elite politik lokal dan elite agama di Kota Pasuruan dalam kontestasi Pemilihan Presiden Tahun 2019. Serta bagaimana elite politik lokal dan elite agama mempertahankan kepentingannya dalam kontestasi pemilihan presiden tahun 2019 di Kota Pasuruan. Penelitian yang digunakan dalam hal ini adalah jenis penelitian kualitatif deskriptif. Selanjutnya Fokus dalam penelitian ini adalah dinamika interaksi antara elite politik lokal dan elite agama dalam kontestasi Pemilihan Presiden Tahun 2019 di Kota Pasuruan. Pokok substansial yang yang diteliti adalah variabel pola relasi antara elite politik lokal dengan elite agama dalam upaya memenangkan calon presiden tahun 2019. Serta Identifikasi terkait pengaruhnya di masyarakat dalam kontestasi Pemilihan Presiden Tahun 2019 di Kota Pasuruan.

Subjek penelitian yang dianalisis antara lain terdiri dari beberapa narasumber baik dari elite politik lokal dan tokoh agama pimpinan pondok pesantren di Kota Pasuruan. Sumber data dipilih dan 
menggunakan teknik wawancara bersifat purposive sampling. Purposive sampling adalah teknik pengambilan sampel sumber data dengan pertimbangan tertentu (Sugiono 2016). Alasan menggunakan purposive sampling adalah karena tidak semua subjek penelitian memiliki kriteria yang sesuai dengan fenomena yang diteliti. Oleh karena itu penulis memilih menggunakan teknik purposive sampling yang menerapkan kriteria harus dipenuhi oleh subjek peneliti. Adapun subjek penelitian harus memenuhi salah satu kriteria di bawah ini sebagai berikut:

1. Elite agama yang mempunyai basis massa dan madrasah atau lembaga pendidikan di kota Pasuruan.

2. Elite politik lokal terdaftar menjadi anggota aktif partai politik, menduduki jabatan politik, dan mempunyai basis massa.

Instrumen penelitian yang digunakan dalam penelitian ini berupa pedoman wawancara yang telah dibuat oleh peneliti sesuai dengan tema penelitian. Serta tidak lupa alat perekam suara untuk merekam wawancara yang dilakukan antara peneliti dengan narasumber. Peneliti menggunakan analisis kualitatif untuk menganalisis data. Informasi yang diperoleh melalui wawancara dalam penelitian ini dianalisis secara kualitatif dengan berpedoman pada kerangka teoretik guna memberikan gambaran yang tepat pada fenomena yang diteliti. Analisis data dimulai dengan membuat transkrip hasil wawancara dengan cara memutar kembali rekaman wawancara kemudian menuliskan kata-kata yang sesuai dengan apa yang ada telah direkam dalam recorder tersebut.

Proses analisis data kualitatif yaitu dengan menghubungkan hasil temuan dengan referensi dan teori yang berlaku dan mencari hubungan di antara sifat-sifat kategori. Kemudian hasil wawancara disusun untuk mengetahui kategori tertentu, atau pokok permasalahan tertentu yang menunjuk pada permasalahan penelitian. Selanjutnya akan dilakukan interpretasi deskriptif dengan mengacu pada landasan teoritik yang digunakan, didukung dengan data-data pelengkap, dan dibandingkan dulu hingga kini serta dengan hasil studi literatur untuk menjawab pola dinamika interaksi antara elite politik lokal dengan elite agama dalam kontestasi pemilihan presiden tahun 2019 di Kota Pasuruan.

\section{KERANGKA TEORETIK}

\section{Elite Politik dan Elite Politik Lokal}

Elite politik menurut Suzanne Keller adalah sekelompok kecil atau orang yang mempunyai pengaruh atau kekuasaan dimasyarakat untuk mengambil dan melaksanakan sebuah keputusan politik. Elite politik berasal dari kata elite atau bahasa latin eligere seorang pilihan yang mempunyai peranan penting dalam suatu kelompok masyarakat tertentu (Keller, 1963). Elite politik lokal juga didefinisikan oleh Nurhasim, . di mana elite politik lokal adalah elite yang berkuasa dalam struktur politik di tingkat lokal. Penjelasan politik lokal adalah politik di level provinsi, kabupaten/ kota. Topik dan isu masalah yang dibahasa dalam politik lokal berupa demokrasi, birokrasi, otonomi daerah, partisipasi warga, akuntabilitas pemerintah. Berdasarkan teori ini maka pemimpin politik di level lokal tersebut dikenal sebagai sebutan elite politik lokal (Chalik, 2017). 


\section{Kekuasaan Elite Politik dan Elite Agama}

Elite politik mempunyai kekuasaan yang kemudian dijelaskan oleh Robert Putnam. Robert Putnam seorang ilmuan politik dari Harvard University yang membahas kekuasaan elite politik. Dalam penjelasan oleh Putnam kekuasaan digambarkan seperti piramida yang mempunyai tingkatan. Dimulai dari tingkat pertama pengambil keputusan hingga tingkatan kedua yang memilik bentuk pengaruh, namun tidak dalam proses pengambilan keputusan. Tingkatan ketiga adalah masyarakat yang melaksanakan sebuah keputusan politik. Steven Lukes sebagai ilmuan politik juga menjelaskan tentang bentuk kekuasaan politik yang terdiri dari dua macam. Pertama adalah bentuk kekuasaan yang dapat dilihat dalam struktur formal pemerintah. Dalam hal ini seperti kekuasaan dalam eksekutif, yudikatif dan legislatif. Kedua adalah bentuk kekuasaan tersembunyi atau hidden power. Kekuasaan tersembunyi merupakan kekuasaan yang tidak terlihat dalam sebuah struktur pemerintahan namun berimplikasi besar terhadap keputusan politik.

Elite agama adalah sosok yang memiliki kekuasaan dalam bentuk pengaruh dimasyarakat elite agama mempuyai kedudukan dan kekuasaan yang berbeda dengan elite politik. Di mana elite-elite agama kekuasaannya adalah hidden power. Kekuasaan seperti ini menjadikan kyai sebagai elite yang istimewa. Clifford Geertz adalah ilmuan dari Amerika Serikat yang juga antropolog menjelaskan bentuk kekuasaan kyai dalam istilah culture broker. Culture broker menjadikan kyai sebagai penghubung dalam nilai-nilai budaya yang ada sejak dahulu untuk di jelaskan kepada masyarakat. Clifford Geertz juga menjelaskan tentang jenis dari tipologi kyai yang kemudian terbagi menjadi 3 macam. Pertama sebagai kyai netral terhadap kegiatan politik dalam hal ini kyai ini masih berpartisipasi politik namun memilih untuk tidak menyerukan dukungan atau terjun langsung dalam politik. Selanjutnya adalah kyai yang masuk dalam kegiatan politik secara aktif. Kyai ini aktif dalam kegiatan politik praktis secara langsung. Terakhir adalah kyai yang tidak peduli dengan politik. Dalam hal ini kyai ini lebih memilih menghindar terhadap kegiatan politik (Suprayogo, 2009).

Miriam Budiarjo juga menjelaskan kekuasaan elite dalam kekuasaan kebudayaan Jawa, di mana kekuasaan yang digunakan adalah behavioristis kekuasaan yang berdasarkan aspek lingkungan sekitar yang memiliki pengaruh. Dalam hal ini elite agama sebagai sosok yang mempunyai pengaruh di lingkungan masyarakat itu sendiri. Elite yang mempunyai kedudukan dimasyarakat adalah elite unggul. Elite ini akan mentransformasikan kekuasaan ke masyarakat itu sendiri yang bersifat mengikat. Dimensi kekuasaan juga sangat terkait dengan modal yang digunakan. Modal ini berupa modal sosial dan modal ekonomi yang memiliki tujuan untuk mempengaruhi masyarakat.

\section{PEMBAHASAN}

\section{Interaksi antara Elite Politik Lokal dan Elite Agama}

Interaksi adalah bentuk komunikasi politik yang terjadi di antara elite agama dengan elite politik. Interaksi yang terjadi di kota Pasuruan pada umumnya dilakukan secara pribadi maupun secara struktural institusi. Berdasarkan hasil wawancara yang sudah dilakukan di antara elite politik dan elite 
agama telah terjadi interaksi secara pribadi seperti yang dilakukan oleh $\mathrm{H}$. Abdulah Junaedi dari partai PKB. Interaksi ini menurut beliau sudah lazim umum dilakukan makan sebelum atau sesudah Pemilu. Interaksi ini sudah menjadi warna dalam kegiatan pemilu oleh elite politik dan elite agama. Bentuk interaksi ini bertujuan menciptakan hubungan yang baik antara elite politik dengan elite agama. Elite dari partai PKB tersebut menjelaskan bahwa dirinya aktif menjalin komunikasi dengan beberapa tokoh agama di Kota Pasuruan. Urgentsi menjaga silaturahmi dalam interaksi secara pribadi sengaja diciptakan secara terus menerus untuk membangun relasi antara pemerintah dengan masyarakat. Elite agama mempunyai peran penting dalam masyarakat karena mempunyai simpatisan dan basis massa yang besar. Elite politik lokal secara umum akan menjalin hubungan baik dengan elite agama yang ada di Kota Pasuruan. Hal ini tidak terlepas bagaimana elite politik yang harus memposisikan diri di dalam masyarakat. Penulis menganalisis bahwa upaya yang dilakukan oleh elite politik lokal adalah untuk mendapatkan legitimasi oleh masyarakat itu sendiri. Dalam gambar di bawah ini penulis menjelaskan berbagai bentuk kepentingan yang dilakukan oleh elite politik lokal kepada elite agama. Hal ini dilakukan mengingat elite agama mempunyai posisi yang penting dalam masyarakat.

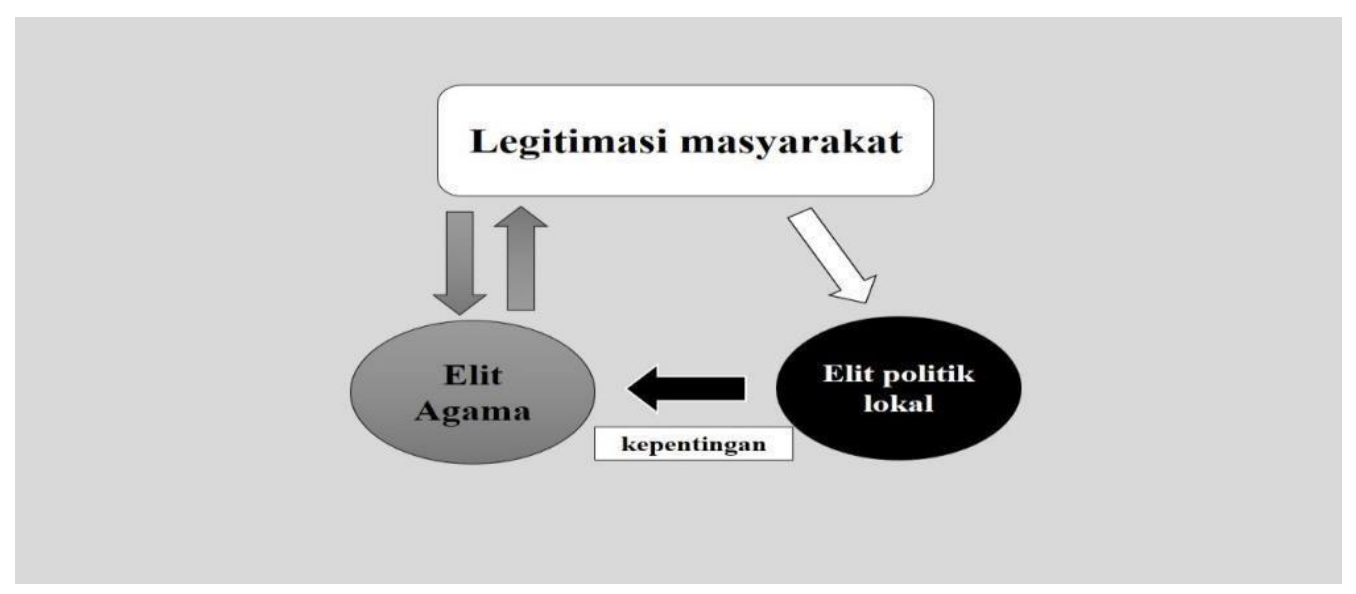

Gambar 1. Bagan interkasi antara elit politik lokal dan elite agama

Interaksi oleh elite politik lokal dengan elite agama mempunyai pengaruh dalam hasil pemilihan presiden 2019. Seperti contoh interaksi antara H. Abdullah Junaedi dengan KH Idris Hamid yang membawa dampak positif dengan hasil pemilu presiden 2019 di wilayah khususnya kediaman KH Idris Hamid dengan kemenangan oleh pasangan Jokowi Ma'ruf. Selanjutnya untuk wilayah daerah pemilihan dari H. Abdullah Junaedi juga dimenangkan oleh pasangan Jokowi Ma'ruf yang sekaligus juga berdampak perolehan electoral suara di daerah pemilihan 3 atau Kecamatan Purworejo. Sehingga kemenangan hasil pilpres pasangan Jokowi Ma'ruf tidak terlepas adanya peran dari kedua tokoh tersebut baik H. Abdullah Junaedi dengan KH Idris Hamid.

\section{Interaksi Elite Politik dan Elite Agama Sebelum Pemilu}

Interaksi politik oleh elite politik dan elite agama akan menjadi warna yang selalu menghiasi serangkaian proses pemilu. Pemilu menjadi kulminasi untuk merebut kekuasaan secara legal dan sah. Pemilu yang melibatkan elite politik dalam upaya meyakinkan masyarakat untuk memilihnya kembali 
dalam pemilu. Dalam upaya untuk meyakinkan masyarakat tidak harus terjun ke dalam masyarakat itu sendiri atau melalui simpatisan. Melainkan dengan cara elite politik menggunakan pendekatan kepada tokoh masyarakat yang memiliki massa yang cukup besar. Dalam pemilu tahun 2019 di Kota Pasuruan elite politik lokal intens melakukan pendekatan kepada elite agama. Sehingga dari pendekatan ini diharapkan elite agama membantu elite politik dalam proses pemenangan di pemilu tahun 2019 khususnya pemilu presiden.

Habib Taufiq Assegaf selaku tokoh agama dari kalangan umat Islam menyebutkan hal yang sama tentang sebuah permintaan oleh elite politik untuk mengarahkan dukungan kepada salah satu paslon tertentu di pemilihan Presiden tahun 2019. Namun dalam hal ini Habib Taufiq Assegaf menyampaikan bahwa hanya mendukung Muhammad SAW Rasulllah. Dalam hal lain Habib Taufiq Assegaf menyebutkan dalam berbagai macam tausiahnya yang mengindikasikan dukungan kepada pasangan Prabowo Subianto. Salah satunya adalah adanya pendapat “ jangan ikuti ulama” yang menjadi peliharaan Umaroh, namun ikutilah ulama' yang berada di luar Umaroh”. Berdasarkan ini menjadi isyarat tentang dukungan dan preferensi pilihan dari Habib Taufiq Asssegaf dalam pemilihan presiden tahun 2019. Dalam hal ini Prabowo Subianto yang mendapatkan dukungan penuh dari Ijtima' Ulama' II. Fakta ini juga memberi dampak positif dengan suara Prabowo Subianto yang menang di kediaman Habib Taufiq Assegaf. Selain itu persentase kemenangan Jokowi di wilayah kecamatan kediaman Habib Taufiq Assegaf yang tipis.

Analisis yang dalam hal ini menunjukkan adanya peran Habib Taufiq Assegaf di wilayah tersebut. Hal ini mengingat Habib Taufiq Assegaf sebagai tokoh ulama' yang sangat disegani dan menjadi panutan masyarakat kota Pasuruan. Apabila perhitungan secara kalkulasi politik di mana Kecamatan Panggungrejo merupakan basis massa dari partai PKB dan Golkar berdasarkan hasil perolehan suara partai politik dari pemilu 2019, seharusnya Jokowi-Ma'ruf meraih suara lebih dari $80 \%$ di wilayah tersebut. Namun kehadiran Habib Taufiq Assegaf di wilayah itu serta beberapa pernyataan tentang indikasi arah dukungan kepada salah satu calon presiden 2019 menjadi salah satu faktor dari $40 \%$ suara Prabowo-Sandi. Kepentingan politik itu akan selalu mewarnai kehidupan berbangsa dan bernegara tidak terkecuali proses pemilu tersebut (Muhyidin, 2016). Steven Lukes yang menjelaskan tentang bentuk kekuasaan elite agama dalam hidden power sebagai bentuk kekuasaan yang dimiliki. Kekuasaan ini berpengaruh dalam masyarakat, namun kekuasaan tersebut tidak digunakan dalam sebuah penyelenggaraan negara atau institusi formal. gambar bagan di bawah ini akan menjadi gambaran tentang interaksi yang dilakukan oleh elite politik dan elite agama. 


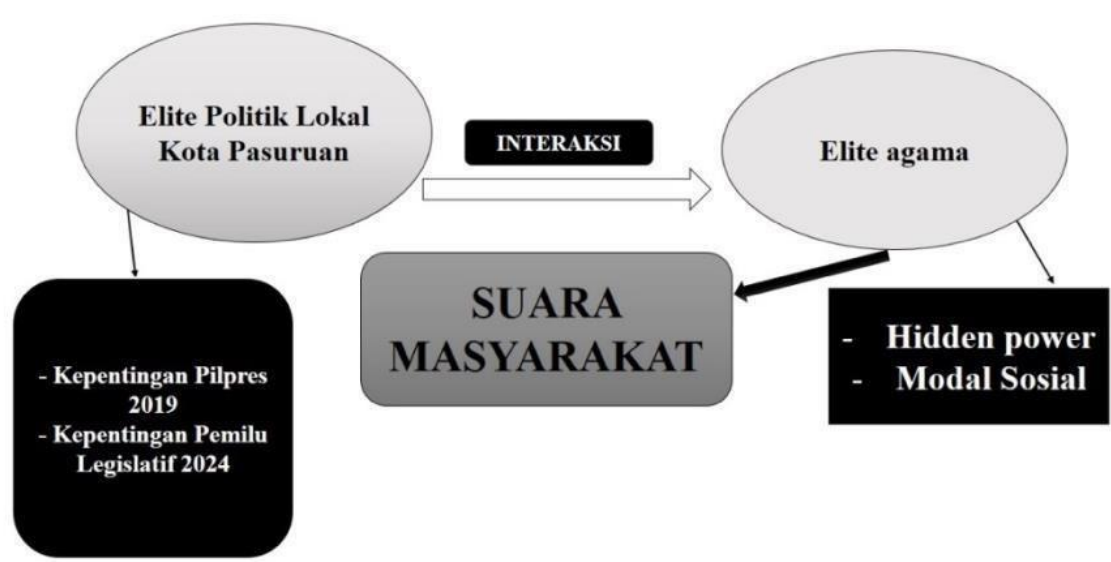

Gambar 2. Interaksi elite lokal dan agama sebelum pemilihan presiden

\section{Kepentingan Elite Politik Lokal dan Elite Agama}

Elite politik lokal kota Pasuruan mempunyai tugas dari partai untuk memenangkan proses pemilu tahun 2019. Berbagai macam manuver dilakukan oleh elite politik tersebut untuk memenangkan calon pilihan presiden tahun 2019. Pericles menjabarkan kepentingan sebagai bentuk keinginan. Kepentingan politik tentu akan selalu menghiasi dalam kehidupan dan berbangsa. Serta bentuk kepentingan politik tersebut tidak terlepas oleh elite politik itu sendiri.

Berdasarkan hasil temuan di lapangan sebagian besar elite politik lokal memanfaatkan posisinya sebagai anggota DPRD Kota Pasuruan untuk mempengaruhi masyarakat. Persoalan yang melatarbelakangi kepentingan elite politik lokal di Kota Pasuruan untuk memenangkan pemilihan presiden 2019. Pertama perintah partai politik kedua faktor adanya tokoh NU yang menjadi wakil presiden dan selanjutnya sejalan dengan visi dan misi. Seperti yang disampaikan oleh Muhammad Nawawi anggota DPRD Kota Pasuruan dari partai Nasdem, sehingga penulis menggambarkan bentuk kepentingan dan latar belakang kepentingan elite politik lokal di bawah ini.

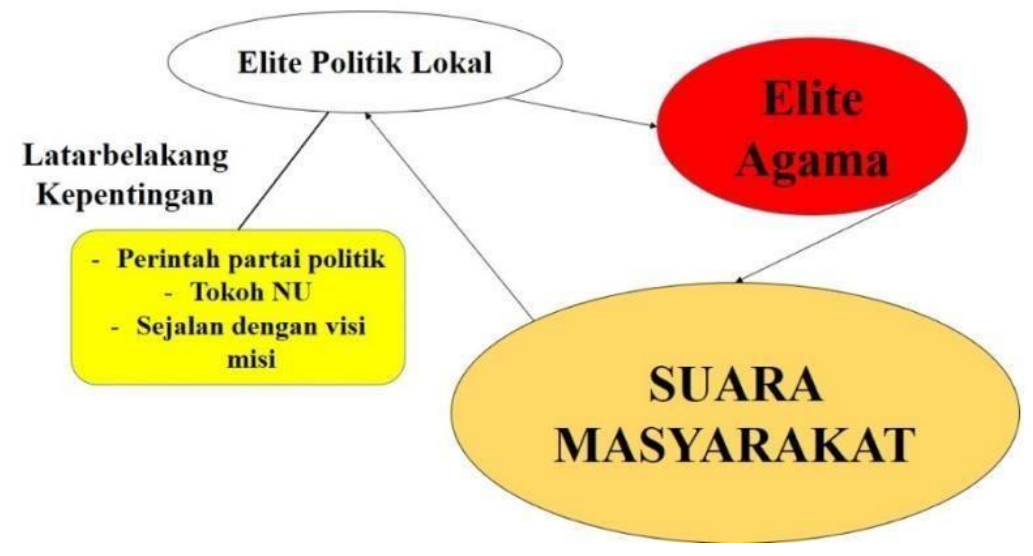


Latar belakang Kyai Ma'ruf amin yang menjadi tokoh NU atau Ra'is Am menjadi faktor utama kepentingan yang dilakukan oleh elite politik lokal Kota Pasuruan. Sebagian besar masyarakat Kota Pasuruan juga warga nahdiyyin atau warga NU. Pernyataan Muhammad Nawawi juga mempertegas sekaligus menjadi penegas faktor dukungan masyarakat kepada pasangan Jokowi Ma'ruf.

\section{Kepentingan Elite Agama}

Kontestasi pemilihan presiden tahun 2019 tidak terlepas dari peranan elite agama. Elite agama menjadi sosok yang penting dalam menjaga perdamaian dan kesejukan di dalam masyarakat. Hal ini sesuai dengan nilai-nilai dan transformasi dari agama yang dianut masing-masing. Miriam Budiarjo juga menjelaskan dalam dari kekuasaan tradisional Jawa. Salah satu di antaranya elite agama memiliki modal sosial yang digunakan untuk mempengaruhi masyarakat. Modal sosial yang dimiliki didapatkan melalui proses yang lama dan panjang.

Keith R. Legg mencoba menjelaskan tentang kepentingan dan relasi kuasa oleh elite agama tentang patron klien. Elite agama sebagai patron yang mempunyai sebuah pengaruh dan power. Klien adalah pihak dari orang yang diperintah oleh patron atau masyarakat. Bentuk dari pola hubungan antara patron dan klien yang menunjukkan tidak ada hubungan yang horizontal atau setara. Elite agama di Kota Pasuruan mempunyai peran sebagai seorang patron dan masyarakat adalah klien (Legg, 1982). Hubungan interaksi ini didasarkan karena seorang patron mempunyai modal sosial ilmu dibidang agama dan kharisma. Sosok seperti Habib Taufiq Assegaf yang mempunyai massa dan begitu dicintai masyarakat. Hal ini juga di ikuti seperti Dwi Handono dari FKUB Kristiani yang mempunyai basis massa di umat kristiani. Pola hubungan ini nampak tidak setara mengingat dalam penjelasan Keith R. Legg.

Elite agama tersebut berkepentingan untuk masing-masing memenangkan pasangan calon presiden 2019 dengan caranya. Hal ini juga terkait banyak rantai kepentingan yang didasari seperti aspek ideologis, hingga permintaan elite politik. Sri Rejeki sebagai tokoh agama menyampaikan bahwa adanya permintaan dukungan oleh elite politik yakni salah satunya Sutirta. selanjutnya Sri Rejeki juga menyampaikan tentang pentingnya memenangkan pasangan Jokowi-Ma'ruf untuk melindungi eksistensi dari umat katolik tersebut. Sehingga kepentingan politik identitas menjadi salah satu penyebab Sri Rejeki memberikan dukungan kepada pasangan Jokowi-Ma'ruf. Elite agama memiliki social learning sebagai modal utama dalam mempengaruhi masyarakat. Pola bentuk pemahaman agama terbuka terhadap lingkungan. Elita agama lebih atau kyai mempunyai pandangan sebagai simbol menjaga kesucian agama.

\section{Kepentingan Elite Politik Lokal dan Elite Agama}

Dinamika interaksi antara elite politik lokal dengan elite agama akan terus terjadi di dalam politik di kota Pasuruan. Setiap elite politik memiliki kepentingan tersendiri dalam pilpres tahun 2019. 
Keterlibatan kyai dalam politik tidak terlepas dari kesadaran mereka sebagai penyandang peran-peran sosial. Kyai memandang bahwa dirinya sebagai ulama atau pewaris nabi berkewajiban melibatkan diri pada persoalan umat yang membedakan di antara peran Umaroh. Sedangkan Umaroh memberikan makna partai politik dan pejabat pemerintahan berbeda. Terdapat kewenangan yang berbeda antara ulama dan Umaroh. Ulama bertugas memberikan pelayanan berkaitan dengan agama dan umaroh pemerintah berwenang mengurus pemerintahan. Kedua bidang ini harus berkedudukan secara terpisah dan berfungsi saling melengkapi. Dalam konstelasi pemilihan presiden 2019 masing-masing elite politik dan elite agama akan berkompetisi untuk mempertahankan kepentingannya. Seperti dalam penjelasan di bawah ini oleh salah satu elite agama di kota Pasuruan yakni Hasjim As'ari.

Hasjim Asy'ari selaku ketua DPD Nasdem kota Pasuruan menyampaikan tentang bentuk kepentingan politik kaitanya dengan pemilu presiden 2019. Bahwa polarisasi yang terjadi di ini disebabkan elite agama yang masuk ke dalam dunia politik praktis. Menurut Hasjim Asy'ari bahwa hal ini akan merugikan dari tokoh agama tersebut karena menurut Hasjim Asy'ari situasi yang ada di nasional berbeda dengan yang terjadi di oleh persebaran media sosial Hasjim Asy'ari berpendapat kebanyakan dari tokoh agama termakan oleh berita hoax yang ada di media sosial.

Berdasarkan pernyataan di atas menunjukkan adanya bentuk persaingan kepentingan antara elite politik dan elite agama, karena di Pasuruan elite agama tidak semuanya mendukung sesuai dengan pilihan elite politik tersebut. Berdasarkan hal tersebut dapat dianalisis adanya konflik yang terjadi dengan saling melempar pernyataan. Akan tetapi, secara umum antara elite politik lokal dan elite agama mempunyai kepentingan masing-masing. Seperti kepentingan dari elite politik lokal adalah berupaya memenangkan calon presiden tahun 2019 sesuai dengan arahan dari partainya, sedangkan kepentingan utama dari elite agama adalah menjaga kedamaian kondusivitas di tengah masyarakat. Namun elite agama juga mempunyai kepentingan lain untuk memenangkan pasangan calon presiden 2019 demi eksistensi dirinya. Dinamika antara elite politik lokal dan elite agama yang terlihat di Kota Pasuruan disebabkan beberapa faktor di antaranya:

1. Adanya perbedaan preferensi dukungan di antara elite politik lokal dan elite agama yang terjadi di Kota Pasuruan.

2. Adanya afiliasi politik yang tidak terlihat antara elite politik lokal dan elite agama.

3. Di antara elite agama dan elite politik mereka secara umum tidak terikat satu sama lain. Namun mereka ada yang mempunyai keterikatan seperti H. Abdullah Junaedi dengan tokoh kyai NU seperti KH Abdul Khalim.

Kyai hingga saat ini tetap memiliki pengaruh yang kuat terhadap kehidupan masyarakat. Harapan Kyai dan pandangan masyarakat dalam memandang posisi ulama kyai selalu menekankan tanggung jawab dirinya untuk memimpin masyarakat agar tidak tersesat dalam mengarungi hidup sementara masyarakat meletakkan kyai sebagai figur yang harus diteladani agar hidupnya sesuai dengan tuntutan agama. Tingkat kepatuhan terhadap kyai ini tentu sebanding dengan karakter santri 
masyarakat. Dimana kyai menjadi satu-satunya rujukan ketaatan yang bersifat mutlak. Dinamika interaksi antara elit politik lokal dan elite agama dalam hal ini menjadi pertarungan yang tidak akan ada habisnya. Mengingat culture yang selalu menghiasi dan dipertahankan hingga sampai saat ini di Kota Pasuruan adalah cuture pesantren dan kyai sebagai elite agama memanfaatkan posisi tersebut. Akan tetapi tidak semua elite agama menggunakan posisi tersebut untuk kepentingan pragmatis mereka.

Peranan dari elite agama dalam pilpres tahun 2019 sangat mempengaruhi preferensi pilihan politik masyarakat Kota Pasuruan. Hasil pemilu presiden 2019 di mana seharusnya Jokowi-Ma'ruf dengan kekuatan partai politik yang kuat di Pasuruan hanya mampu menang diangka $55 \%$ suara. Tentu hal ini juga tidak terlepas dari elite agama yang mepunyai dukungan kepada pasangan Prabowo Subianto yang salah satunya adalah Habib Taufiq Assegaf. Modal sosial yang dimiliki oleh Habib Taufiq Assegaf ini juga berperan sangat signifikan terhadap hasil di setiap kecamatan di Kota Pasuruan. Pasangan Jokowi Ma'ruf tidak mampu menang 70\% suara di setiap kecamatan. Sehingga sosok Habib Taufiq Assegaf pengaruhnya tidak hanya di wilayah kecamatan kediamannya melainkan di seluruh Kota Pasuruan.

\section{SIMPULAN}

Kontestasi pemilihann presiden tahun 2019 di Kota Pasuruan melahirkan sebuah kompetisi diantara elite politik dengan elite agama. Pasangan Jokowi-Ma'ruf lebih unggul di Kota Pasuruan. Hal ini disebabkan kekuatan partai politik yang mendominasi di Kota Pasuruan berasal dari partai pengusung Jokowi-Ma'ruf. Kedua sebagian elite agama memberikan dukungan penuh kepada pasangan Jokowi Ma'ruf, seperti kumpulan ulama' dan kyai Nahdatul ulama' pasuruan yang di pimpin oleh KH Idris Hamid.

Namun di sisi lain, terdapat pandangan yang berbeda dengan bentuk dukungan secara tidak langsung kepada pasangan Prabowo Subianto-Sandiaga Uno. Dukungan ini juga diberikan oleh salah satu elite agama di Kota Pasuruan, yakni Habib Taufiq Assegaf. Sehingga ditemukan di lapangan perolehan suara dari Prabowo Subianto-Sandiaga Uno mampu menyaingi pasangan Jokowi Ma'ruf dengan selisih 5\% suara. Dukungan tidak langsung yang diberikan Habib Taufiq Assegaf ini dapat dilihat tentang penyampaian kegiatan ceramah yang mengindikasikan arah dukungan kepada pasangan Prabowo. Interaksi antara elite politik lokal dan elite agama terjadi dalam pemilihan presiden tahun 2019 di Kota Pasuruan. Interaksi ini berwujud sebuah permintaan dari elite politik kepada elite agama untuk menyerukan dukungan kepada salah satu pasangan calon presiden tahun 2019.

Kepentingan elite politik lokal dan elite agama dalam kontestasi pemilihan presiden tahun 2019 saling beriringan dan terdapat yang berbeda. Elite agama yang beriringan untuk mendukung JokowiMa'ruf mempertahankan kepentingannya dengan mendukung secara langsung dan deklarasi terbuka. Sedangkan elite agama yang mendukung pasangan Prabowo Subianto-Sandiaga mendukung dengan cara tidak langsung. Selain itu hasil ini menggambarkan bahwa elite agama masih mempunyai peranan 
kuat di tengah masyarakat Kota Pasuruan, sehingga preferensi dukungan kyai di Kota Pasuruan menjadi salah satu hal penting dalam pemilihan presiden 2019.

\section{DAFTAR PUSTAKA}

Budiarjo M (1984) Aneka Pemikiran Tentang Kuasa dan Wibawa. Jakarta: Sinar Harapan.

Connstantine B (2018) Kiai Idris Hamid Keluarkan Maklumat terkait Pemilihan Gubernur Jatim Mendatang. Surya, 6 Juni 2018. Diakses 13 Mei 2019, dari https://www.google.com/amp/s/surabaya.tribunnews.com/amp/2018/06/06/Kiai-IdrisHamid Keluarkan-Maklumat-Terkait-Pemilihan-Gubernur-Jatim-Mendatang/ Harrison L (2007) Metodologi Penelitian Politik. Jakarta: Preneda Media Grup.

Keller S (1963) Penguasa dan Kelompok Elite. Jakarta: CV Rajawali.

Kominfo (2018) Sejarah Kota Pasuruan. Diakses 18 Mei 2019, dari https://pasuruankota.go.id/sejarahpasuruan/

Legg KR (1982) Tuan, Hamba, dan Politisi. Jakarta: Yayasan Obor Jakarta.

Muhyidin A (2016) Aktor politik dan kepentingan. Jurnal Politik, 2(1). https://doi.org/10.7454/jp.v2i1.86

Nurhasim M (2005) Konflik antar Elite Politik Lokal dalam Pemilihan Kepala Daerah. Yogyakarta: Pustaka Pelajar Offset.

Rahma M (2019) Putra Kyai Hamid Pasuruan Serukan Pilih Jokowi-Ma'ruf pada Pilpres 2019. Warta Bromo, 25 Maret 2019. Diakses 3 April 2019, dari https://www.wartabromo.com/2019/03/25/gus-idris-serukan-pilih-Jokowi-marufpadapilpres2019/

Sugiyono (2016) Metode Penelitian Kuantitatif, Kualitatif dan R\&D. Bandung: PT Alfabhet.

Suprayogo I (2009) Kyai dan Politik (Membaca Citra Politik Kyai). Malang: UIN-Maliki Press. 